\title{
Cerebral blood flow
}

velocity during isov-

olemic hemodilution and

subsequent autologous

blood retransfusion

\author{
J. Mühling MD, \\ M.G. Dehne MD, \\ A. Sablotzki MD, \\ G. Hempelmann MD
}

Purpose: To quantify the influence of hematocrit on cerebral blood flow velocity (CBFV) in healthy volunteers undergoing acute isovolemic hemodilution (HD) with hydroxyethyl starch $10 \%$ (HES) and subsequent autologous whole blood retransfusion (RT).

Methods: In 1 | volunteers $20 \mathrm{ml} \cdot \mathrm{kg}^{-1}$ blood was withdrawn over 30 min and simultaneously replaced with HES $10 \%$. Thirty min later, RT was started at a constant rate over 30 min. Recorded parameters included: CBFV, pulsatility-index (PI) and resistance-index (RI) of the middle cerebral artery (MCA). Blood pressure (BP), heart rate $(\mathrm{HR})$, hemoglobin $(\mathrm{Hb})$, hematocrit $(\mathrm{Hc})$ peripheral $\mathrm{O}_{2}$-saturation $\left(\mathrm{SpO}_{2}\right), \mathrm{P}_{\mathrm{ET}} \mathrm{CO}_{2}$, arterial oxygen content $\left(\mathrm{CaO}_{2}\right)$ and cerebral arterial $\mathrm{O}_{2}$-transport $\left(\mathrm{C}_{\mathrm{E}}-\mathrm{DO}_{2}=\mathrm{CaO}_{2} \times \mathrm{Vm}-\mathrm{MCA}\right)$ were monitored.

Results: An average of 1570 total blood was withdrawn which resulted in a decrease in $\mathrm{Hb}$ from $14.5 \mathrm{mg} \cdot \mathrm{dl}^{-1}$ to $10.3 \mathrm{mg} \cdot \mathrm{dl}^{-1} ; \mathrm{Hc}$ (and $\mathrm{CaO}_{2}$ ) decreased from $41.8 \%\left(19.8 \mathrm{ml}^{-\mathrm{dl}^{-1}}\right.$ ) to $29.6 \%\left(14.2 \mathrm{ml} \cdot \mathrm{dl}^{-1} ; P<0.01\right)$. VmMCA increased from $61.2 \mathrm{~cm} \cdot \mathrm{sec}^{-1}$ to $77.3 \mathrm{~cm} \cdot \mathrm{sec}^{-1}(P<0.01)$. Following RT, Vm-MCA decreased again, but remained higher than baseline $(P<0.01)$. PI decreased by $13 \%$ following RT $(P<0.05)$. There were no changes in $\mathrm{RI}, \mathrm{HR}, \mathrm{BP}, \mathrm{SpO}_{2}$ and $\mathrm{P}_{\mathrm{ET}} \mathrm{CO}_{2}$. Regression lines could be fitted between $\mathrm{Hc}$ and $\mathrm{Vm}-\mathrm{MCA}, \mathrm{Vm}-\mathrm{MCA}$ and $\mathrm{CaO}_{2}$. and between $\mathrm{HC}$ and $\mathrm{C}_{\mathrm{E}} \mathrm{DO}_{2}$.

Conclusions: Transcranial Doppler changes in blood flow velocities correlated with the simultaneously recorded systemic $\mathrm{Hc}$ and $\mathrm{CaO}_{2}$ values. We found a $2 \%$ increase in $\mathrm{CBFV}$ for each $1 \%$ decrease in $\mathrm{Hc}$ and $\mathrm{CaO}_{2}$.

Objectif : Quantifier l'influence de l'hématocrite sur la vitesse du flux sanguin cérébral (VFSC) chez des volontaires en santé qui subissent une hémodilution isovolémique aiguë $(H D)$ avec de l'amidon hydroxyéthyle $10 \%$ (AHE) et une retransfusion (RT) de sang autologue complet.

Méthode : On a prélevé $20 \mathrm{ml} \cdot \mathrm{kg}^{-1}$ de sang chez || volontaires pendant 30 min et on l'a remplacé simultanément par de l'AHE $10 \%$. Trente minutes plus tard, on a amorcé la RT à vitesse constante pendant $30 \mathrm{~min}$. Les paramètres enregistrés comprennent : VFSC, l'indice de pulsatilité (IP) et l'indice de résistance (IR) de l'artère cérébrale moyenne (ACM). La tension artérielle (TA), la fréquence cardiaque ( $\mathrm{FC})$, l'hémoglobine $(\mathrm{Hb})$, l'hématocrite $(\mathrm{Ht} t)$, la saturation en $\mathrm{O}_{2}$ du sang périphérique $\left(\mathrm{SpO}_{2}\right)$, la $\mathrm{P}_{\mathrm{ET}} \mathrm{CO}_{2}$, la concentration en oxygène du sang artériel $\left(\mathrm{CaO}_{2}\right)$ et le transport d' $\mathrm{O}_{2}$ artériel cérébral $\left(\mathrm{C}_{\mathrm{E}}-\mathrm{DO}_{2}=\mathrm{CaO}{ }_{2} \times \mathrm{Vm}-\mathrm{ACM}\right)$ ont été mesurés.

Résultats : Environ $1570 \mathrm{ml}$ de sang total ont été prélevés, ce qui a provoqué une hausse de l'Hb de 14,5 $\mathrm{mg} \cdot \mathrm{dl}^{-1}$ à $10,3 \mathrm{mg} \cdot \mathrm{dl}^{-1} ; \mathrm{l}^{\prime} \mathrm{Ht}(\mathrm{et} \mathrm{la} \mathrm{CaO})$ ont diminué de $41,8 \%\left(19,8 \mathrm{ml} \cdot \mathrm{dl}^{-1}\right)$ à $29,6 \%\left(14,2 \mathrm{ml} \cdot \mathrm{dl}^{-1} ; \mathrm{P}<0,01\right)$. $V \mathrm{~m}$ - ACM a augmenté de $61,2 \mathrm{~cm} \cdot \mathrm{sec}^{-1}$ à $77,3 \mathrm{~cm} \cdot \mathrm{sec}^{-1}(P<0,01)$. Après la RT, Vm-ACM a subi une autre baisse, mais est demeuré plus haut que la donnée de base $(P<0,01)$. L'IP a diminué de $13 \%$ après la RT $(P<$ 0,05). II n'y a pas eu de changement d'IR, $\mathrm{FC}, T \mathrm{~T}, \mathrm{SpO}_{2}$ et $\mathrm{P}_{\mathrm{ET}} \mathrm{CO}_{2}$. Les courbes de régression se situaient entre $\mathrm{Ht}$ et $\mathrm{Vm}-\mathrm{ACM}, \mathrm{Vm}-\mathrm{ACM}$ et $\mathrm{CaO}_{2}$, et entre $\mathrm{Ht}$ et $\mathrm{C}_{\mathrm{E}} \mathrm{DO}_{2}$.

Conclusion : Les changements au Doppler transcrânien des vitesses du flux sanguin correspondent aux enregistrements simultanés de l'Ht générale et des valeurs de $\mathrm{CaO}_{2}$. Nous avons noté une augmentation de VFSC de $2 \%$ pour chaque baisse d'Hc et de $\mathrm{CaO}_{2}$ de $1 \%$.

From the Department of Anaesthesiology and Intensive Care Medicine, Justus-Liebig-University Rudolf-Buchheim-Strasse 7, 35385 Giessen, Germany.

Address correspondence to: Dr. med. J. Mühling. Phone: 0641-99-44401; Fax: 0641-99-44409.

Accepted for publication March 20, 1999 


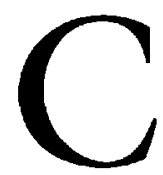

LINICAL estimation of hemodilution or hemoconcentration dependent changes on CBF due, for example, to acute bleeding during surgery, transfusion or volume substitution therapy has relied mainly on noninvasive methods. Transcranial Doppler sonography, the most readily available technique, is extensively used during surgery and intensive care units for estimation of cerebral blood flow because measurement of $\mathrm{CBF}$ cannot be performed at the bedside or in critical acute situations which require immediate therapy away from the apparatus. Thus, the anticipated effects of physiological variables on CBFV should be known to avoid misinterpretation of CBFV during periods of hemodilution or hemoconcentration. One of the major mechanisms which may explain the relationship between the augmentation of CBF following hemodilution is a direct rheologic effect due to a decrease in hematocrit, but there is controversy about the relative influence of this mechanism on CBFV alteration. , $^{1,2,3,4}$

The goal of this study was to quantify the influence of hematocrit on CBFV in healthy, non-medicated volunteers undergoing 1) a time-standardized, body weight-corrected and volume-balanced isovolemic hemodilution with hydroxyethyl starch $10 \%$ (withdrawal of $20 \mathrm{ml} \cdot \mathrm{kg}^{-1}$ blood) and 2) standardized retransfusion of autologous whole blood (with continuous monitoring of factors that influence transcranial Doppler sonography, such as blood pressure, heart rate, $\mathrm{P}_{\mathrm{ET}} \mathrm{CO}_{2}$, systemic arterial oxygen content, peripheral arterial oxygen saturation, body temperature and calculated cerebral oxygen transport).

\section{Methods}

The study was approved by the local ethics committee and volunteers $(n=11)$ gave their informed, written consent at least one day before the study. Biometric data of the volunteers are shown in Table I. Persons with preexisting cardio-pulmonary, cerebral, neurological, or allergic disorders as well as those taking drugs were excluded from this study.

Before examination, all study subjects were allowed $30 \mathrm{~min}$ to reach equilibrium. Acute iso-volemic hemodilution (HD) was performed by collecting $20 \mathrm{ml} \cdot \mathrm{kg}^{-1}$ blood at a constant rate over a period of $30 \mathrm{~min}$. Blood was withdrawn from a large bore intravenous cannula in the right antecubital fossa while an equal amount of hydroxyethyl starch 10\% (HES; molecular weight = $200 \cdot 10^{3}$ Dalton; substitution $=0.5$ ) was infused simultaneously into a vein in the contralateral antecubital fossa. After $30 \mathrm{~min}$ rest, autologous whole blood was retransfused (RT) at a constant rate over $30 \mathrm{~min}$. Completion of retransfiusion was followed by a second resting period of $30 \mathrm{~min}$. Measurements were recorded at $15 \mathrm{~min}$ intervals as follows: prior to $\mathrm{HD}(\mathrm{Tl})$, after HD $50 \%$ (T2), directly after cessation of HD (T3), 15 min (T4) and 30 min (T5) after HD, after RT 50\% (T6), immediately after RT (T7), $15 \mathrm{~min}$ (T8) and 30 min after RT (T9). Throughout the study volunteers were seated in the conventional blood-donor position and rested while recordings were made at an ambient room temperature of about $22^{\circ} \mathrm{C}$. We chose this position to exclude possible risks of hemodilution as well as to provide the best conditions for our volunteers during investigation. ${ }^{9}$ Blood flow velocity in the middle cerebral artery (MCA) was measured using a transcranial Doppler pulsed 2-MHZ system (TC2-64B®, EME, Germany) via the transtemporal approach at a depth of approximately $45-55 \mathrm{~mm}^{5}$ The flow probe was fixed in position and all measurements were made at the same depth respectively by the same operator. Registered parameters included systolic, mean, and diastolic blood flow velocity (Vs-MCA, Vm-MCA and Vd-MCA, respectively), from which the pulsatility-index (PI) and the resistance-index (RI) were calculated according to the following formulas: PI= (Vs-MCA - Vd-MCA)/ Vm-MCA, RI= (Vs-MCA - Vd-MCA)/ Vs-MCA. Blood flow velocities were registered for one minute each before the results were averaged for statistical analysis. Blood pressure was measured (cannula via the left radial artery) and arterial oxygen pressures $\left(\mathrm{PaO}_{2}\right)$ blood hemoglobin and hematocrit were determined with an automated blood gas analyzer. Pressure transducers were positioned between heart and brain level to exclude greater differences in cerebral perfusion pressure and systemic blood pressure. For this reason mean cerebral perfusion pressure was slightly overestimated and systemic blood pressure sightly underestimated by approximately $7 \mathrm{~mm} \mathrm{Hg}$. Arterial oxygen content $\left(\mathrm{CaO}_{2}\right)$ was calculated as $\left(\mathrm{CaO}_{2}=\left(\mathrm{Hb} \times \mathrm{O}_{2} \mathrm{Sat} \times 1.36\right)\right.$ $+\left(\mathrm{PaO}_{2} \times 0.003\right)$ and an equivalent of cerebral $\mathrm{O}_{2}-$ transport $\left(\mathrm{C}_{\mathrm{E}}-\mathrm{DO}_{2}\right)$ was calculated as $\mathrm{CaO}_{2} \times \mathrm{Vm}^{-}$ MCA. Heart rates were obtained using ECG. Oral body temperatures were measured and cutaneous temperatures from the forearm and the lower leg were recorded. Peripheral arterial oxygen saturation was measured continuously by pulse oximetry using a sen-

TABLE I Number, age, height, weight and withdrawal volume of the studied volunteers.

\begin{tabular}{ll}
\hline Volunteers $(n=11)$ & mean (range) \\
\hline age $[\mathrm{yr}]$ & $29(26-33)$ \\
height $[\mathrm{cm}]$ & $182.5(172-191)$ \\
weight $[\mathrm{kg}]$ & $78.5(72-98)$ \\
withdrawal volume $[\mathrm{ml}]$ & $1570(1440-1960)$ \\
\hline
\end{tabular}


sor placed over the ear lobes, and $\mathrm{P}_{\mathrm{ET}} \mathrm{CO}_{2}$ was monitored intermittently in the respiratory air at all measurement times for one minute periods before the results were averaged for statistical analysis. We avoided using additional invasive means to monitor circulation according to the findings of Singbartl and coworkers ${ }^{6}$ and Fan $e t a l^{7}$ as well as of monitoring of viscosity in respect of findings of Brückner et al. ${ }^{8}$

After the results were demonstrated to be normally distributed, statistical methods included one-factor analysis of variance for repeated measures (ANOVA) and the Scheffe-test, where appropriate. Probability levels of $P<0.05$ were considered significant. The data are given as means $\pm S D$.

\section{Results}

Isovolemic hemodilution (mean withdrawal volume $1570 \pm 165 \mathrm{ml}$; Table I) and subsequent retransfusion of autologous whole blood was well tolerated by all subjects. No adverse effects were observed during the study in any volunteer.

Heart rate and blood pressure (Figure 1) remained constant throughout the study. There were no changes in continuously registered peripheral arterial oxygen saturation, the $\mathrm{P}_{\mathrm{ET}} \mathrm{CO}_{2}$ at any time (Table II). The $\mathrm{CaO}_{2}$ decreased during $\mathrm{HD}$ from $19.8 \mathrm{mg} \cdot \mathrm{dl}^{-1}$ (T1) to $14.2 \mathrm{mg} \cdot \mathrm{dl}^{-1}$ and recovered to $16.6 \mathrm{mg} \cdot \mathrm{dl}^{-1}$ (T9) after RT (Table II). While oral and lower leg temperatures did not change, the temperatures recorded from the forearm (where autologous blood was withdrawn) decreased from $33.3^{\circ} \mathrm{C}$ (Tl) to $32.5^{\circ} \mathrm{C}$ (T8, $P<0.05$; Table II). Hemodilution decreased hemoglobin concentration from $14.5 \mathrm{~g} \cdot \mathrm{dl}^{-1}$ (T1) to $10.3 \mathrm{~g} \cdot \mathrm{dl}^{-1}(\mathrm{~T} 4)(P<0.01)$, and increased again to $12.1 \mathrm{~g} \cdot \mathrm{dl}^{-1}$ (T9) after retransfusion (Figure 2). Hematocrit decreased from $41.8 \%$ (T1) to $29.6 \%$
$(\mathrm{T} 4 ; P<0.01)$ and recovered to $35.0 \%$ after retransfusion (T9; Figure 2). At the end of the study (T9), neither hematocrit nor hemoglobin levels attained the initial values at $\mathrm{Tl}(P<0.01)$. Correlating with decreasing hemoglobin- and hematocrit values, cerebral blood flow velocities changed during HD (Figure 3 ). The initial $\mathrm{Vm}-\mathrm{MCA}$ of $61.2 \mathrm{~cm} \cdot \mathrm{sec}^{-1}$ (T1) increased during $\mathrm{HD}$ to $77.2 \mathrm{~cm} \cdot \mathrm{sec}^{-1}(\mathrm{~T} 3 ; P<0.01$ ). $15 \mathrm{~min}$ after completion of HD Vm-MCA was still higher than baseline values (T4: $76.1 \mathrm{~cm} \cdot \mathrm{sec}^{-1} ; P<$ 0.01 ). During retransfusion the cerebral blood flow velocity decreased again in close correlation with the now rising hemoglobin and hematocrit levels. Cerebral blood flow velocity $30 \mathrm{~min}$ after completion of retransfusion $\left(69.2 \mathrm{~cm} \cdot \mathrm{sec}^{-1}\right.$; T9) was still higher than baseline values $(P<0.01)$. For the whole study there were linear negative correlations between hematocrit and Vm-MCA (Vm-MCA [cm. $\left.\mathrm{sec}^{-1}\right]=-1.29 \times$ $\mathrm{Hc}+114.7, \mathrm{r}=0.86, P<0.00001 ;$ Figure 4$)$, between $\mathrm{CaO}_{2}$ and $\mathrm{Vm}-\mathrm{MCA}\left(\mathrm{Vm}-\mathrm{MCA}\left[\mathrm{cm} \cdot \mathrm{sec}^{-1}\right]=-4,1 \times\right.$ $\mathrm{V} \mathrm{CaO}{ }_{2}\left[\mathrm{ml} \cdot \mathrm{dl}^{-1}\right]+138,2 ; P<0,00001 ; \mathrm{r}=0,85$; Figure 5) as well as between hematocrit and $\mathrm{C}_{\mathrm{E}} \mathrm{DO}_{2}$ $\left(\mathrm{C}_{\mathrm{E}}-\mathrm{DO}_{2}=-6,97 \times \mathrm{Hc}+1366,5 ; \mathrm{P}<0,001 ; \mathrm{r}=0,36\right.$; Figure 6).The pulsatility-index (PI) and resistanceindex (RI) showed no changes during HD, but PI decreased during retransfusion (T7-T9) compared with baseline values $(P<0.05$; Figure 7$)$.

\section{Discussion}

One of the major mechanisms which explain the relationship between CBFV and hematocrit is a direct hemorrheologic effect as a result of a decrease in hematocrit, but there is still no agreement of the relationship. In this study marked changes in cerebral blood flow velocity in the middle cerebral artery occurred as a result of the acute hemodilution and

TABLE II End-tidal $\mathrm{PCO}_{2}\left(\mathrm{P}_{\mathrm{et}} \mathrm{CO}^{2}\right)$, peripheral oxygen saturation $\left(\mathrm{S}_{\mathrm{pO}} \mathrm{O}^{2}\right)$, oral- $\left(\mathrm{T}_{\text {oral }}\right)$, lower leg- $\left(\mathrm{T}_{\text {leg }}\right)$, forearm temperatures $\left(\mathrm{T}_{\text {forearm }}\right)$ and arterial oxy-gen content $\left(\mathrm{CaO}_{2}=\mathrm{Hb} \times \mathrm{O} 2-\mathrm{Sat} \times 1,36\right)+\left(\mathrm{PaO}_{2} \times 0,003\right)$ during the investi-gation. $\mathrm{Tl}=$ prior to hemodilution $(\mathrm{HD})$, $\mathrm{T} 2=$ after $50 \% \mathrm{HD}, \mathrm{T} 3=$ directly after cessation of $\mathrm{HD}, \mathrm{T} 4=15$ minutes and $\mathrm{T} 5=\mathbf{3 0} \mathrm{min}$ after $\mathrm{HD}$, T6= after $50 \%$ retransfusion $(\mathrm{RT})$, T7 = immediately after RT (T7), T8=15 min and T9=30 min after RT. ${ }^{*} P<0.05$ compared with baseline values (before HD)

\begin{tabular}{|c|c|c|c|c|c|c|}
\hline & $\begin{array}{l}P_{E T} C_{2} \\
(m m H g)\end{array}$ & $\underset{(\%)}{\mathrm{SpO}_{2}}$ & $\begin{array}{l}T_{\text {oral }} \\
\left({ }^{\circ} \mathrm{C}\right)\end{array}$ & $\begin{array}{l}T_{\operatorname{leg}} \\
\left({ }^{\circ} \mathrm{C}\right)\end{array}$ & $\begin{array}{l}T_{\text {fonarm }} \\
\left({ }^{\circ} \mathrm{C}\right)\end{array}$ & $\begin{array}{l}\mathrm{CaO}_{2} \\
(m l \cdot d l)\end{array}$ \\
\hline $\mathrm{T} 1$ & $36 \pm 3$ & $99 \pm 0.5$ & $36.9 \pm 0.3$ & $33.5 \pm 1.5$ & $33.3 \pm 1.4$ & $19.8 \pm 0.8$ \\
\hline $\mathrm{T} 2$ & $36 \pm 4$ & $99 \pm 0.5$ & $36.8 \pm 0.2$ & $33.5 \pm 1.5$ & $33.2 \pm 1.3$ & $16.9 \pm 0.8^{*}$ \\
\hline $\mathrm{T} 3$ & $36 \pm 3$ & $99 \pm 0.4$ & $36.8 \pm 0.2$ & $33.5 \pm 1.5$ & $33.3 \pm 1.1$ & $14.7 \pm 0.7^{\star}$ \\
\hline T4 & $36 \pm 4$ & $99 \pm 0.4$ & $36.8 \pm 0.2$ & $33.5 \pm 1.5$ & $33.2 \pm 1.4$ & $14.2 \pm 0.6^{*} \dagger$ \\
\hline T5 & $36 \pm 3$ & $99 \pm 0.5$ & $36.9 \pm 0.2$ & $33.5 \pm 1.5$ & $33.2 \pm 1.3$ & $14.6 \pm 0.8^{*}$ \\
\hline T6 & $37 \pm 3$ & $99 \pm 0.6$ & $36.8 \pm 0.2$ & $33.5 \pm 1.5$ & $32.7 \pm 1.5$ & $15.4 \pm 0.8 *$ \\
\hline T7 & $36 \pm 4$ & $99 \pm 0.5$ & $36.7 \pm 0.2$ & $33.5 \pm 1.5$ & $32.5 \pm 1.5^{\star}$ & $16.3 \pm 0.9^{\star}$ \\
\hline T8 & $37 \pm 4$ & $99 \pm 0.6$ & $36.8 \pm 0.2$ & $33.5 \pm 1.5$ & $32.5 \pm 1.5^{\star}$ & $16.5 \pm 0.8^{*}$ \\
\hline $\mathrm{T} 9$ & $37 \pm 4$ & $99 \pm 0.6$ & $36.8 \pm 0.2$ & $33.5 \pm 1.5$ & $32.6 \pm 1.5^{*}$ & $16.6 \pm 0.8^{*}$ \\
\hline
\end{tabular}




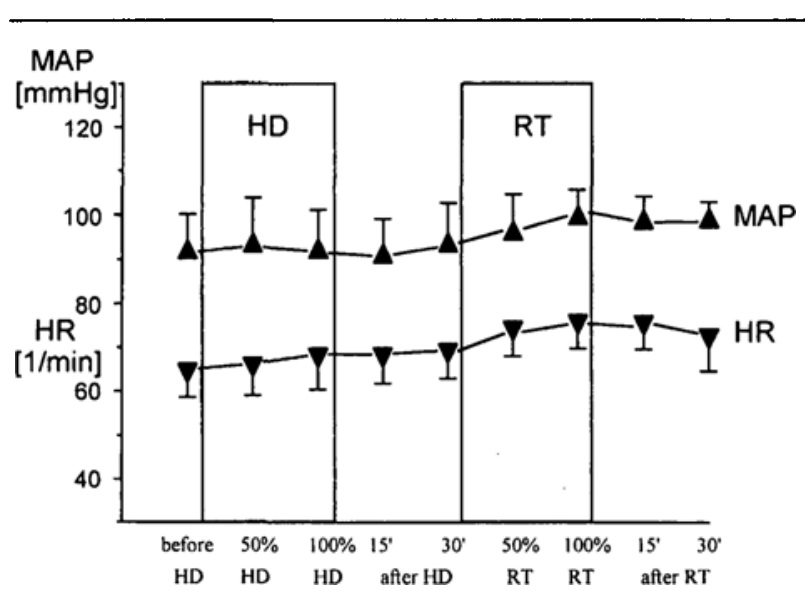

FIGURE 1 Mean arterial pressure (MAP) and heart rate (HR) during the investigation (mean $\pm \mathrm{SD}$ ). $\mathrm{HD}=$ =isovolemic hemodilution, RT=retransfusion, "=minutes.

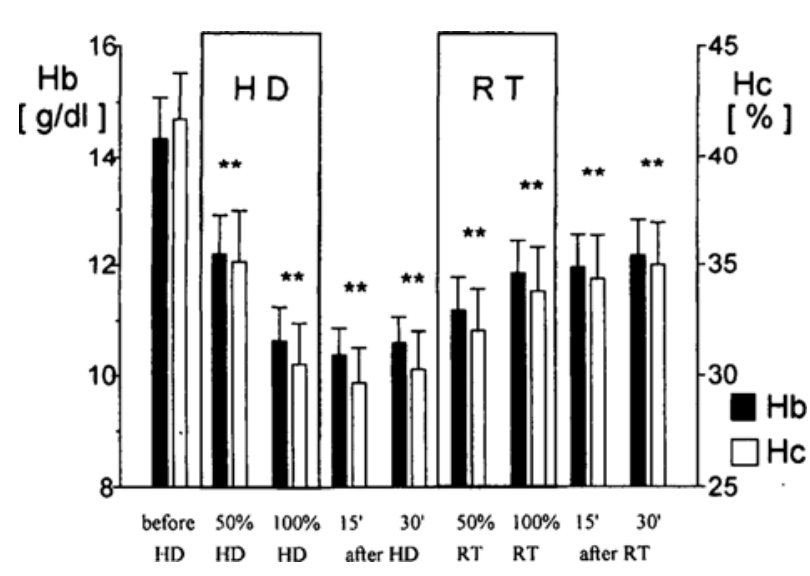

FIGURE 2 Changes in hemoglobin ( $\mathrm{Hb}$ ) and hematocrit ( $\mathrm{Hc}$ ) during the investigation (mean $\pm \mathrm{SD}$ ). $\mathrm{HD}$-isovolemic hemodilution, $\mathrm{RT}=$ retransfusion, ${ }^{\prime}=$ minutes. $\dagger P<0.01$ ( $\mathrm{Hb}$ and $\mathrm{Hc}$ ) compared with baseline values (before HD).

subsequent retransfusion. Transcranial Doppler sonography recorded changes in blood flow velocity, measured over the whole study, showed a negative correlation with the simultaneously recorded systemic hematocrit and hemoglobin values. In our hemodiluted and hemoconcentrated volunteers we found a $2 \%$ increase in CBFV for each $1 \%$ decrease in the hematocrit. According to our previous results ${ }^{9}$ these findings are very comparable to the hemodilution changes found in animal studies for CBF alterations. In animal studies using dogs and cats a negative correlation

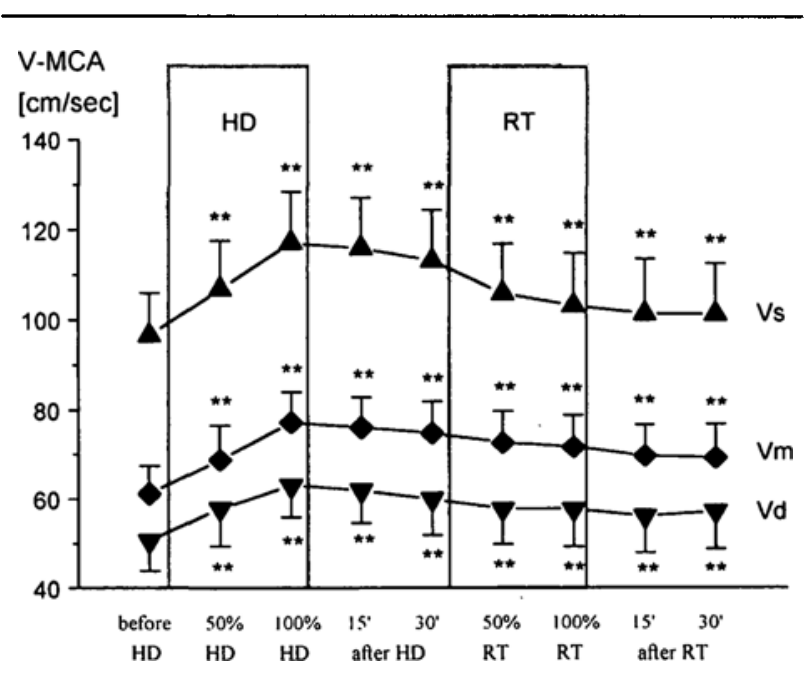

FIGURE 3 Changes in systolic (Vs-MCA), diastolic (Vd-MCA), and mean blood flow velocities (Vn-MCA) in the middle cerebral artery (MCA) during the investigation (mean $\pm S D$ ).

$\mathrm{HD}=$ isovolemic hemodilution, $\mathrm{RT}=$ retransfusion, $=$ =minutes. $\dagger P<0.01$ compared with baseline values (before HD).

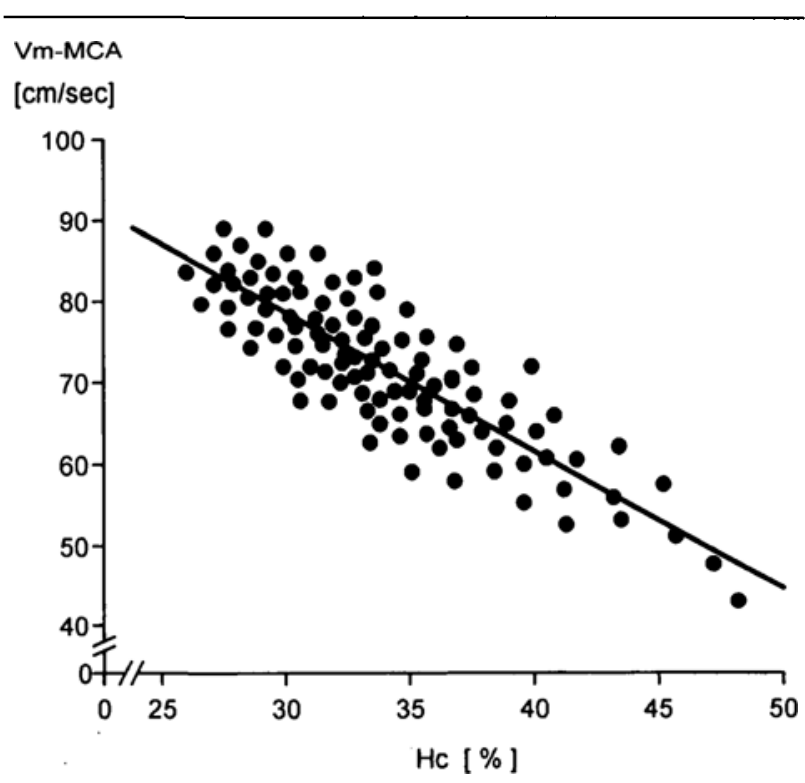

FIGURE 4 Relationship between hematocrit (Hc) as percent and mean blood flow velocities (Vm-MCA) during the investigation. Equation for linear negative correlation curve is $\mathrm{Vm}-\mathrm{MCA}$ $\left[\mathrm{cm} \cdot \mathrm{sec}^{-1}\right]=-1.29 \times \mathrm{Hc}[\%]+114.7 ; P<0,00001 ; \mathrm{r}=0,86 \mathrm{n}=99$.

between cerebral blood flow and the hematocrit was shown. ${ }^{10-13}$ In a study by Maruyama et al ${ }^{13}$ the correlation between CBF and systemic hematocrit changes could be observed down to hematocrit values of $5 \%$. 


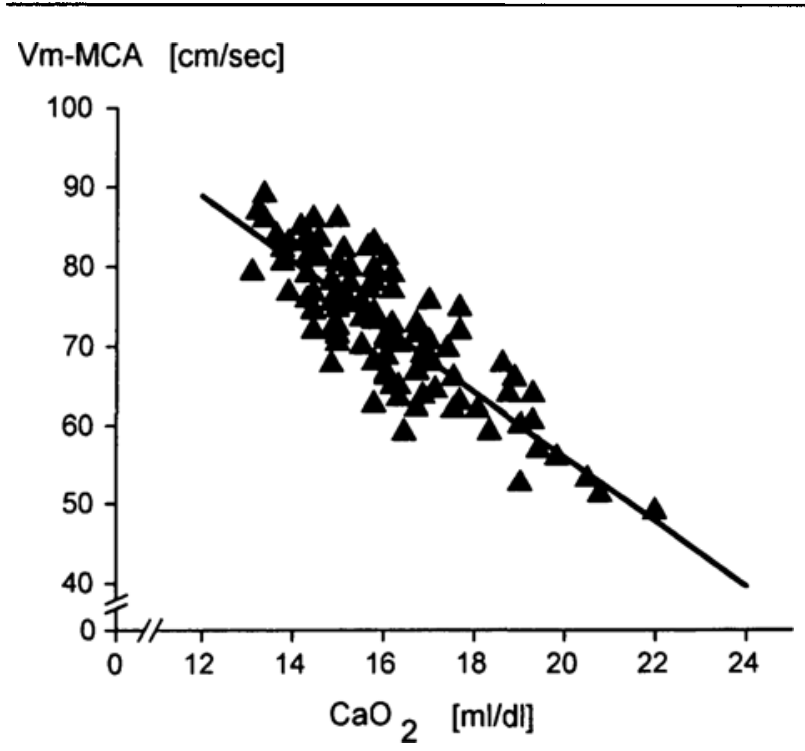

FIGURE 5 Relationship between arterial oxygen content $\left(\mathrm{CaO}_{2}\right.$ $\left.=\mathrm{Hb} \times \mathrm{SpO}_{2} \times 1.36+\left(\mathrm{PaO}_{2} \times 0.003\right)\right)$ as $\left[\mathrm{ml} \cdot \mathrm{dl}^{-1}\right]$; and mean blood flow velocities $1(\mathrm{Vm}-\mathrm{MCA})$ during the investigation. Equation for linear negative correlation curve is $\mathrm{Vm}-\mathrm{MCA}$ $\left[\mathrm{cm} \cdot \mathrm{sec}^{-1}\right]=-4.11 \times \mathrm{CaO}_{2}\left[\mathrm{ml} \cdot \mathrm{dl}^{-1}\right]+138.2 ; P<0.00001$; $r=0,85 ; n=99$.

These studies in which CBF has been measured during hemodilution have shown that there is $1 \%$ to $4 \%$ increase for each $1 \%$ decrease in hematocrit values. The effects of hematocrit alteration following hemodilution or hemoconcentration on CBFV are also seen diffusely, but there is still controversy on the relative influence because these studies all have limitations.

In elderly, sickle cell anemia-, stroke- and transient ischemic attack patients, Brass et al. ${ }^{14,15}$ and Ameriso and coworkers ${ }^{16}$ found a non-linear mathematical correlation between the cerebral blood flow velocity measured in the middle cerebral artery and the hematocrit. However, pathological states may modify $\mathrm{CBF}$ and CBFV independently from the effects of hematocrit. Furthermore, the studies were conducted under fixed hematocrit and patients who had had a preceding transfusion or hemodilution therapy were excluded. A major criticism is the large range in patient age in these studies which may explain part of the difference of CBFV attributed to changes in hematocrit. The CBFV decreased with age and there was a correlation between age and CBFV. Changes in rheological parameters following hemodialysis, ${ }^{17,18}$ transfusion sickle cell anemia, ${ }^{19}$ partial plasma exchange in polycythemia ${ }^{20}$ or during coronary surgery ${ }^{21}$ can also affect the cerebral circulation. In

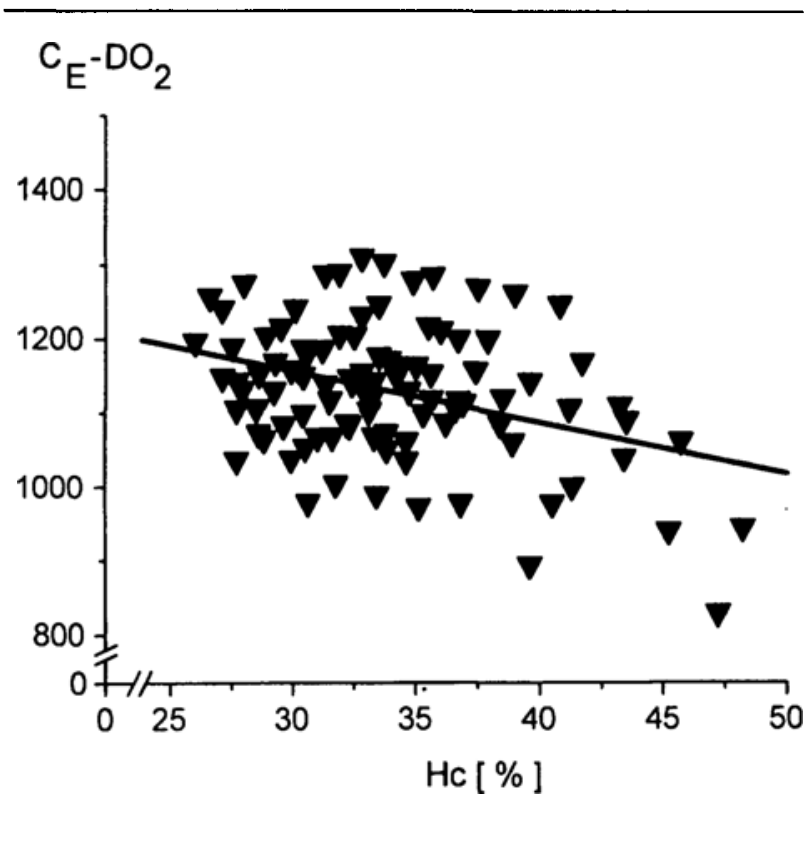

FIGURE 6 Relationship between hematocrit (Hc) as percent and the equivalent of cerebral $\mathrm{O}_{2}$-transport $\left(\mathrm{C}_{\mathrm{E}}-\mathrm{DO} 2=\left[\mathrm{CaO}_{2} \times\right.\right.$ $\mathrm{Vm}-\mathrm{MCA}]$ ) during the investigation. Equation for linear negative correlation curve is $\mathrm{C}_{\mathrm{E}}-\mathrm{DO}_{2}=-6.97 \times \mathrm{Hc}[\%]+1366.5 ; \mathrm{P<}$ $0.001 ; \mathrm{r}=0,36 ; \mathrm{n}=99$.

these studies transfusion therapy, the loss of body weight and the amount of fluid removed during hemodialysis therapy or onset of cardiopulmonary bypass led to changes in cerebral blood flow velocity which were directly related to alterations in hematocrit. In contrast to our results are the findings of Bruder et al., who examined the effect of hemodilution in anesthetized patients and could find no relationship between hematocrit and CBFV. ${ }^{22}$ In this study, measurements were performed only before $(\mathrm{Hc}=38 \%)$ and after hemodilution $(\mathrm{Hc}=30 \%)$ without exact time-, volume- or body weight standardizations (target hematocrit was 30\% and the hemodilution ranged from 350 to $900 \mathrm{ml}$ ). In our opinion, we believe it is impossible to calculate or exclude any correlation between hematocrit and CBFV. Another major limitation was the use of vasoactive anesthetics - for example isoflurane - which are known to influence CBF and CBFV, too.

Hemodilution may also effect the cerebral artery diameter. Thus, it is possible that CBFV did not follow CBF after hemodilution. In animal studies, hemodilution was accompanied either by no change or by vasoconstriction of pial arteries. ${ }^{23-25}$ Furthermore, it has been suggested that vasoconstriction is greater in small $(<100 \mu \mathrm{m})$ than in large $(>100 \mu \mathrm{m})$ arterioles 


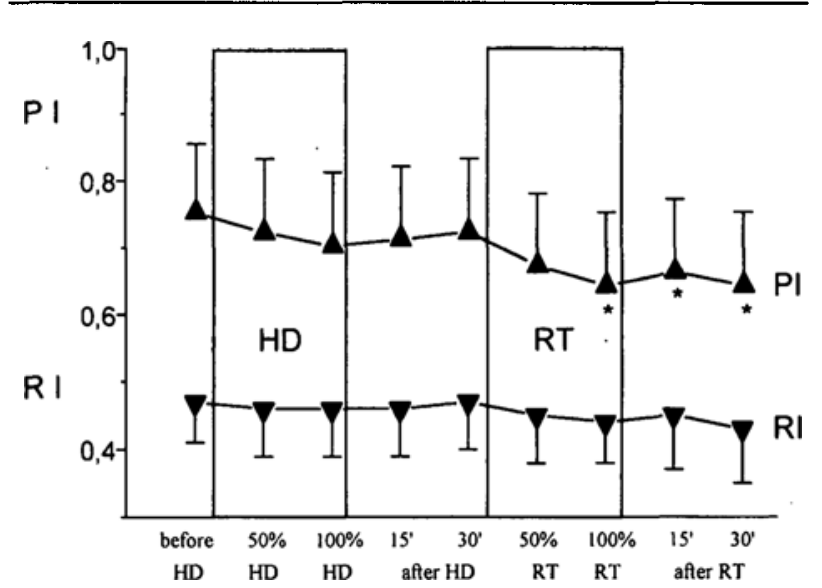

FIGURE 7 Changes in pulsatility-index (PI), [(Vs-MVA - VdMCA) / Vm-MCA] and resistance-index (RI), [(Vs-MCA-Vd$M C A)$ / Vs-MCA] in the middle cerebral artery (MCA) during the investigation (mean $\pm S D$ ). $\mathrm{HD}=$ isovolemic hemodilution, $\mathrm{RT}=$ retransfusion,'=minutes. ${ }^{*} P<0.05$ compared with baseline values (before $\mathrm{HD}$ ).

and that the diameter of basilar cerebral arteries does not change. Muizelaar et al..$^{26}$ found that hemodilution is associated only with small $(-4.4 \%)$ decreases in basilar artery diameter. Our findings may suggest only small changes in middle cerebral artery diameter. The resistance and pulsatility indexes, acting as potential indicators for changed cerebro-vascular resistance, remained virtually constant during the isovolemic hemodilution and during retransfusion there was only a small reduction in the pulsatility index. ${ }^{27}$ In several studies hemodilution induced a decrease in cerebral vascular resistance (CVR). In this study there were no changes of PI or RI during hemodilution and in our opinion the idea that these parameters can be used as an index of CVR should be viewed with caution. ${ }^{28}$ The relationship between CVR and PI -respectively RI- may be disturbed by changes in systemic vascular dynamics or in arterial compliance and the pulsatility of cerebral arteries. These findings may explain the increase in PI despite the decrease in CVR observed during hypotension and additionally, changes of hematocrit may alter visoelastic properties of blood as a medium for wave propagation. Summing up it might be said that small changes in PI are often difficult to explain and should not be attributed to changes in hematocrit.

Another important mechanism to explain the alterations of CBF following hemodilution or hemoconcentration is an autoregulatory response designed to maintain constant oxygen delivery to the brain as a result of an acute decrease of oxygen transport capacity. ${ }^{11,29-32}$ In our study we calculated cerebral oxygen delivery using the arterial oxygen content and the $\mathrm{CBFV}$ as an index of CBF and applied linear regression analyses of mean CBFV against mean $\mathrm{CaO}_{2}$ as well as mean $\mathrm{C}_{\mathrm{E}} \mathrm{DO}_{2}$ against hematocrit. As we found previously in healthy volunteers, changes in $\mathrm{CaO}_{2}$ correlated negatively with the simultaneously recorded cerebral blood flow velocity. We found a $2 \%$ increase in $\mathrm{CBFV}$ for each $1 \%$ decrease in the $\mathrm{CaO}_{2}$ values. Furthermore, following hemodilution we observed a decrease of about $10 \%$ in mean $\mathrm{C}_{\mathrm{E}} \mathrm{DO}_{2}$ which was negatively correlated to changes in systemic hematocrit. These findings are comparable with hemodilution changes found in animal studies which both compared the effects of hypoxemia and hemodilution adjusted to produce a comparable decrease in $\mathrm{CaO}_{2}$. In normal rabbits Korosue et al. ${ }^{11}$ observed similar increases in CBF with hypoxic hypoxia and hemodilution and concluded that arterial oxygen content was the controlling factor in both cases. Hudack et al. ${ }^{33}$ investigated the independent effects of $\mathrm{CaO}_{2}$ and red blood cell concentration in mediating the decrease of CBF following hemoconcentration with methemoglobin containing red cells in unanesthetized newborn lambs. The CBF increased during infusion but did not return to normal. The authors concluded that both viscosity and arterial oxygen content had an effect in $\mathrm{CBF}$ alteration. Our results seems to confirm investigations which showed that cerebral oxygen delivery decreases during extensive hemodilution. In this connection, Todd $e t a l^{34}$ concluded that, in pentobarbital-anesthetized rabbits, tissue oxygen content and not the systemic oxygen transport capacity was the dominant factor influencing the CBF response to decreases in either $\mathrm{PaO}_{2}$ or hematocrit. While calculated cererbal oxygen delivery was well maintained in hypoxic animals it decreased during hemodilution. Brain oxygen extraction ratios, as well as venous oxygen partial pressures, were higher in hemodiluted than in hypoxic animals. The authors suggested that there were different adaptive responses to acute hypoxemia or hemodilution and argued that at similar CBF and arterial oxygen content, tissue oxygen content may be higher during hemodilution. Furthermore, our results are comparable with the findings of Hino et $a l .^{12}$ in volunteers. They examined the effects of hemodilution on cerebral hemodynamics and oxygen metabolism using positron emission tomography and oxygen-15-labeled gas inhalation and observed no improvement in oxygen transport or tissue oxygen delivery in the human brain, although there was an increase in $\mathrm{CBF}$. 
According to the results of this study, the cerebral blood flow velocities in the middle cerebral artery of neurologically healthy volunteers undergoing an acute isovolemic hemodilution with hydroxyethyl starch $10 \%$ and subsequent autologous whole blood retransfusion were directly influenced in a linear fashion down to hematocrit values of $30 \%$. Direct negative linear correlations between hemodilution using hydroxyethyl starch $10 \%$ and hemoconcentration induced changes in systemic hematocrit and arterial oxygen content values, and changes in middle cerebral artery blood flow velocity as well as between equivalent of cerebral oxygen delivery and hematocrit were shown. The regressions agree with findings concerning the influence hematocrit and arterial oxygen content on $\mathrm{CBF}$ as well as concerning the influence of extensive hemodilution on cerebral oxygen delivery in animal models. The implications are that these parameters should be taken into account for a comprehensive understanding of perioperative CBFV alterations. As this study in conscious volunteers show and according to our former results, transcranial Doppler sonography may be used to estimate the effect of hemodilution on $\mathrm{CBF}$, provided that factors which influence transcranial Doppler sonography are maintained and controlled.

\section{References}

1 Brïckner U, Messmer K. Blood rheology and systemic oxygen transport. Biorheology 1990; 27: 903-12.

$2 \mathrm{Kee} D \mathrm{Jr}$, Wood J. Rheology of the cerebral circulation. Neurosurgery 1984; 15: 125-31.

3 Akiyama H, Ohta S, Suzuki M. Effects of hemodilution on cerebral arterial blood flow velocity and cerebrovascular $\mathrm{CO}_{2}$ reactivity. Masui 1994; 43: 1135-40.

4 Harrison $M$. Influence of hematocrit on the cerebral circulation. Cerebrovasc Brain metab Rev 1989; 1 : 55-6.

5 Aaslid R, Markwalder TM, Nornes $H$. Noninvasive transcranial Doppler ultrasound recording of flow velocities in basal cerebral arteries. J Neurosurg 1982; 57: 769-74.

6 Singbartl G, Schleinzer W. Monitoring in hemodilution. Infusionsther Transfusionsmed 1993; 20: 166-71.

7 Fan $F$, Chen $R$, Schiissler $G$, Chien S. Effects of hematocrit variations on regional hemodynamics and oxygen transport in the dog. Am J Physiol 1980; 238: H545-52.

8 Brückner U, Messmer $K$. Organ blood supply and oxygenation during limited isovolemic hemodilution with 6\% HES 200/ 0.62 and 6\% Dextran 70 (German). Anaesthesist 1991; 40: 434-40.

9 Mübling J, Detsch $O$, Mübling $A$, et al. Extensive isovolemic hemodilution with gelarin and hydroxyethyl starch and its effect on cerebral blood flow velocity and cutaneous microcirculation (German). Anaesthesist 1997; 46: 927-37.
10 Todd M, Weeks J, Warner D. Cerebral blood flow, blood volume and brain tissue hematocrit during isovolemic hemodilution with hetastarch in rats. Am J Physiol 1992; 263: H75-82.

11 Korosue K, Heros R. Mechanism of cerebral blood flow augmentation by hemodilution in rabbits. Stroke 1992; 23: 1487-93.

12 Hino A, Ueda S, Mizukawa N, Imahori $\Upsilon$, Tenjin $H$. Effect of hemodilution on cerebral hemodynamics and oxygen metabolism. Stroke 1992; 23: 423-6.

13 Maruyama M, Shimoji K, Ichikawa T, Hashiba M, Naito $E$. The effects of extreme hemodilutions on the autoregulation of cerebral blood flow, electroencephalogram and cerebral metabolic rate of oxygen in the dog. Stroke 1985; 16: 675-9.

14 Brass L, Prohovnik I, Paplakis S, DeVivo D, Piomelli S, Mohr J. Middle cerebral artery blood velocity and cerebral blood flow in sickle cell disease. Stroke 1991; 22: 27-30.

15 Brass L, Pavlakis S, DeVivo D, Piomelli S, Mohr J. Transcranial doppler measurements of the middle cerebral artery. Stroke 1988; 19: 1466-9.

16 Ameriso S, Paganini-Hill A, Meiselmann H. Fisher M. Correlates of middle cerebral artery blood velocity in the elderly. Stroke 1990; 21: 1579-83.

17 Postiglione A, Faccenda F, Gallota G, Rubba P, Federico $S$. Changes in middle cerebral artery blood velocity in uremic patients after hemodialysis. Stroke 1991; 22: 1508-11.

18 Hata R, Matsumo M, Handa N, Terakawa H, Sugitani $\Upsilon$, Kamada T. Effects of hemodialysis on cerebral circulation evaluated by transcranial Doppler ultrasonography. Stroke 1994; 25: 408-12.

19 Venketasubramanian N, Probovnik I, Hurlet A, Mobr J, Piomelli $S$. Middle cerebral artery velocity changes during transfusion sickle cell anemia. Stroke 1994; 25 : 2153-8.

20 Maertzdorf $W$, Tangelder $G$, Slaaf $D$, Blanco C. Effects of partial plasma exchange transfusion on cerebral blood flow velocity in polycythaemic preterm and small for date newborn infants. Eur J Pediatr 1989; 148: 774-8.

21 Van den Linden J, von Ahn $H$, Ekroth $R$, Tyden $H$. Middle cerebral artery flow velocity during coronary surgery; influence of clinical variables. J Clin Anesth 1990; 2: 7-15.

22 Bruder N, Cohen B, Pellisier D, Francois G. The effect of hemodilution on cerebral blood flow velocity in anestherized patients. Anesth Analg 1998; 86: 320-4.

23 Taylor G, Hudak M. Color Doppler Ultrasound of changes in small vessel diameter and cerebral blood flow during acute anemia in the newborn lamb. Invest Radiol 1994; 29: 188-94. 
24 Hudak M, Jones $M J r$, Popel A, Köbler R, Traystman $R$, Zeger. Hemodilution causes size dependent constriction of pial arterioles in the cat. Am J Physiol 1989; 257: H912-17.

25 Czinn E, Salem M, Crystal G. Hemodilution impairs hypocapnia-induced vaso-constrictor responses in the brain and spinal cord in dogs. Anesth Analg 1995; 80: 492-8.

26 Muizelaar J, Bouma G, Levasseur J, Kontos $H$. Effect of hematocrit variations on cerebral blood flow and basilar artery diameter in vivo. Am J Physiol 1992; 262: H949-54.

27 Czosnyka M, Richards HK, Whitehouse HE, Pickard JD. Relationship between transcranial Doppler- determined pulsatility index and cerebrovascular resistance: an experimental study. J Neurosurg 1996; 84: 79-84.

28 Guilioni $M$, Ursino $M$, Alvisi $C$. Correlations among intracranial pulsatility, intracranial hemodynamics and transcranial Doppler waveform: literature review and hypothesis for future studies. J Neurosurg $1988 ; 22$ : 807-12.

29 Tanaka K, Camarata P, Spellman S, McDonald D, Heros $R$. Optimal timing of hemodilution for brain protection in a canine model of focal cerebral ischemia. Stroke 1996; 27: 906-12.

30 Reasoner D, Ryu K, Hindman B, Cutkomp J, Smith T. Marked hemodilution increases neurologic injury after focal cerebral ischemia in rabbits. Anesth Analg 1996; 82: 61-7.

31 Mirhashemi S, Ertefai S, Messmer K, Intaglietta $M$. Model analysis of the enhancement of tissue oxygenation by hemodilution due to increased microvascular flow velocity. Microvasc Res 1987; 34: 290-301.

32 Krieter $H$, Brückner $U$, Kefalianakis F, Messmer $K$. Does colloid induced plasma hyperviscosity in haemodilution jeopardize perfusion and oxygenation of vital organs? Acta Anaesthesiol Scand 1995; 39: 236-44.

33 Hudak ML, Koebler RC, Rosenberg AA. Effects of hematocrit on cerebral blood flow. Am J Physiol 1986; 251: $\mathrm{H63}-70$.

34 Todd $M$, Wu B, Maktabi $M$, Hindman B, Warner D. Cerebral blood flow and oxygen delivery during hypoxemia and hemodilution: role of arterial oxygen content. Am J Physiol 1994; 267: H2025-31. 